\title{
O CONTROLE DE CONSTITUCIONALIDADE DIFUSO: UMA ANÁLISE DE SUA ORIGEM E DA MODULAÇÃO DE SEUS EFEITOS NO ESPAÇO
}

\section{Geovany Cardoso Jeveaux}

Doutor em Direito pela Universidade Gama Filho (UGF-RJ), Mestre em Direito pela Pontifícia Universidade Católica do Rio de Janeiro (PUC-RJ). Professor de Direito da Universidade Federal do Espírito Santo (UFES) e juiz do trabalho - Tribunal Regional do Trabalho da $17^{\text {a }}$ Região.

Ricardo Gueiros Bernardes Dias

Doutor em Direito pela University of California (San Francisco)/UGF (sanduíche), Mestre em Direito pela UGF/UERJ. Graduado em Direito pela Universidade de Brasília (UnB). Pós-graduado em Direito Comparado pela Cornell/Université Paris 1 (Panthéon-Sorbonne). Professor de Direito da Universidade Federal do Espírito Santo (UFES). Visiting Researcher da Univeristy of California.

\section{Resumo}

O presente estudo visa a realizar uma abordagem acerca da origem do controle difuso de constitucionalidade, ao analisar, de forma crítica, o significado histórico e político do caso Marbury vs Madison, assim como do período que o antecede. Essa análise tem por objetivo desmitificar o parâmetro inicial dessa espécie de controle. Além disso, realiza-se uma investigação detalhada sobre as decisões do Supremo Tribunal Federal (STF) a respeito dos efeitos no espaço no tocante ao controle difuso de constitucionalidade, notadamente quanto aos aspectos transcendentes, vinculantes e erga omnes das decisóes proferidas.

\section{Palavras-chave}

Controle; Constitucionalidade; Efeitos; Difuso; Origem.

\section{Abstract}

This study aims to realize an approach about the origin of the judicial review, to analyze, critically, the historical and political meaning of Marbury vs. Madison case, as the period that precedes it. This analysis aims to demystify the initial parameter. In addition, there will be a detailed investigation into the decisions of the Supreme Court (STF) 
on the effects in space with respect to judicial review, notably about the transcendent aspects, binding and erga omnes of judgments.

\section{Key words}

Judicial; Review; Origin; Supreme; Court; Effects.

\section{Introdução}

Há dois aspectos, no âmbito no controle de constitucionalidade, que parecem nos levar a um lugar-comum se tomarmos como parâmetro a literatura mais básica sobre a temática.

O primeiro deles é relativo à origem do controle de constitucionalidade difuso. Não há como deixar de fazer menção ao caso Marbury vs Madison quando se trata dessa espécie de controle. No entanto, não são poucos também os que, em seus escritos, almejam desmitificá-lo, embora não retirando seu significado histórico. $\mathrm{O}$ que se pretende pelo presente estudo é, no mínimo, a conscientização a respeito do significado da hierarquização das normas em momento anterior ao julgamento.

"Nula é toda a lei oposta a Constituição". Essas palavras são retiradas da decisão de John Marshal no referido caso, o que aparentemente concedia competência a todo magistrado norte-americano para declarar, incidentalmente, a inconstitucionalidade de lei lato sensu em um caso concreto. $\mathrm{O}$ que, hoje, é lugar-comum, não o era no início do seculo XIX. A pirâmide formulada por Kelsen, em que se via a Constituição em seu ápice, nem sempre foi a obviedade.

O presente estudo possui dois focos que, num primeiro momento, poderiam parecer divergentes entre si.

De início, fazermos uma incursão na origem do controle incidental concreto, seja no âmbito do direito comparado, seja no nacional. Pretendeu-se dar um enfoque crítico na análise, na medida em que se investiga o judicial review em período anterior ao caso Marbury vs. Madison, assim como um estudo de alguns aspectos singulares desse controle no âmbito dos EUA.

O outro aspecto que nos levaria ao lugar-comum seria o relativo aos efeitos (principalmente, no espaço) do controle de constitucionalidade difuso. Principalmente (mas não apenas) em razão da adoção histórica da teoria da nulidade das normas constitucionais, criou-se quase uma dogma a respeito dos efeitos ex tunc quando a declaração de constitucionalidade no controle difuso. De outro lado, em razão da própria essência dessa espécie de controle (incidental e concreta), limitou-se, no âmbito espacial, à efiácia entre as partes do processo. 
Sabe-se, no entanto, que nos últimos anos (notadamente na última década), há uma manifesta tendência do Supremo Tribunal Federal em flexibilizar esses dogmas tomando por premissa diversos fatores.

Nesse tópico, é realizada uma detalhada análise das decisóes do Supremo Tribunal Federal a respeito dos efeitos do controle difuso, notadamente quanto ao espaço, a fim de investigar se o próprio STF tem utilizado as expressóes corretas e coerentes referente ao tema.

\section{Uma Abordagem (Crítica) sobre a Origem do Controle de Constitucionali- dade Difuso}

Embora darmos, neste texto, uma prevalência ao termo "difuso" - posto que largamente difundida no âmbito jurisprudência - entendemos que as expressóes incidental e/ ou concreto melhor exemplicam o tema ${ }^{1}$. A essência do controle não é ditada pelo fato de a competência ser difusa entre vários agentes. Embora esse fato seja verdadeiro na maior parte do casos, como o que ocorre no Brasil, temos também que, no plano prático, há casos (de alguns países) em que poucos se utilizam dessa prerrogativa.

E o maior exemplo disso é exatamente o próprio EUA, razão pela qual poderíamos afirmar que merecia, no mínimo, cautela admitirmos que o controle naquele país poderia ser considerado difuso, tendo em vista que, em termos práticos, a competência se "concentra” na mãos de poucos.

Apenas a título de curta menção, podemos citar pequena pesquisa de campo realizada por nós no Estado da Califórnia. Verificamos que um número diminuto de juízes (seja na esfera federal ou estadual), de fato, chegam a deixar de aplicar uma lei em razão de sua inconstitucionalidade em toda sua carreira. Em realidade, não encontramos naquele meio sequer um magistrado que o tenha feito, mas apenas meras (e vagas) mençóes de que "teriam ouvido dizer" que determinado juiz assim teria agido.

Por outro lado, é, sim, da essência desse controle o fato de a discussão sobre a inconstitucionalidade ser mero incidente processual, havendo o que se denomina por vinculação procedimental (SCARANCE, 1991). Da mesma forma, verifica-se que nesse controle há o fim precípuo da solução do caso caso concreto, motivo pelo qual a preferência reside em razões teóricas e práticas.

De qualquer forma, em termos de origem, não são muitos os que se aprofundam a ponto de afastar da tradicional afirmação segundo a qual o controle de constitucionalidade difuso teria sido proveniente do caso Marbury vs Madison.

1 Embora venhamos a utilizar, por diversas vezes no texto, a expressão "difuso", tendo em vista larga utilização jurisprudencial do termo. 
O fundamenetos de Marshall em sua decisão ecoam com ar de certa obviedade para os dias de hoje, posto que o escalonamento/hierarquização é uma premissa aparentemente inafastável no constitucionalismo ocidental. Mas essa obviedade não ocorria na época. Pontes de Miranda, ao comentar acerca da recepçáo européia dessa doutrina, assinala que

(...) basta pensar-se em que, na Alemanha, a sentença do Tribunal do Reich de 4 de novembro de 1925, que se seguiu a de outros tribunais, constituiu assunto sensacional. Tratava-se de ligação à lei e, se a Constituiçáo é a primeira e maior das leis, o que importava em ilogismo era o náo-controle." (MIRANDA, 1946).

Como dissemos, m uma primeira abordagem menos profunda, costuma-se sempre fazer menção ao caso Marbury vs Madison, como parâmetro originário do controle de constitucionalidade. Era o ano de 1801. Fim do mandato de John Adams, derrotado por Thomas Jefferson na eleição anterior. Em seus derradeiros dias, nomeou 42 justices-of-the -peace (juízes que apreciavam causas criminais de menor potencial ofensivo). Ao assumir, Thomas Jefferson, no entanto, impediu o empossamento de todos. William Marbury, um dos nomeados, impetrou mandamus na Suprema Corte dos Estados Unidos, requerendo concessão da segurança para garantir a sua posse.

O cunho político daquela decisão é transparente. Isso é deduzido, inclusive, pela própria ordem dos questionamentos levantados por John Marshall. Ora, se, ao final, se posicionou pela incompetência daquela Corte Suprema, como pode, então, utilizando laudas e laudas, ter adentrado o âmago da questão? O pressuposto é analisado preliminarmente. É assim hoje, e era ontem. Lá e aqui.

Novamente: essa origem realmente, e necessariamente, passa por essa questão da obviedade, que parece não ocorrer, até os dias de hoje, na doutrina norte-americana. Se, de um lado, a maioria vai sustentar a teoria tradicional, segundo a qual o caso Marbury vs Madison veio traçar as linhas preliminares da necessidade da hierarquização da Constituição frente às demais normas, de outro, interessante notar que, até hoje, alguns pesquisadores (PRAKASH, 2003, pp. 887-982) norte-americanos insistem em não aceitar, por exemplo, o controle de constitucionalidade no âmbito das leis federais. Alegam que derivariam de um ativismo judicial proveniente do período pós-colonial.

De uma forma ou de outra, uma posição majoritária (PRAKASH, 2003, pp. 887982) fortalece sua tese em três premissas básicas:

1) Seria o próprio lacônico texto constitucional que consagraria essa doutrina (Article III, Section 2) ao dizer que o poder judiciário teria autoridade sobre todo o direito e a equidade "arising under this Constitution". Ou seja, é como se houvesse, de acordo com o texto constitucional, o seguinte escalonamento: a)Constituição; b)Poder Judiciário: c)Direito e Equidade. 
2) A Constituição ao limitar o poder governamental já daria suporte à doutrina do judicial review. Quer-se dizer: se por um lado o poder judiciário, por si, não poderia "anular" os atos governamentais, por outro, poder-se-ia, sim, afirmar que esse mesmo poder judiciário ao interpretar a Constituição estaria, indiretamente, afetando esse governo.

3) Restou demonstrado que, ao se redigir o texto constitucional, já se entendia que haveria uma espécie de controle do poder legislativo e executivo. Tanto assim é que na Convenção da Filadelfia já não se tinha tanta preocupação em se controlar o poder legiferante, pois a doutrina do judicial review já seria o bastante.

Há robusto estudo (TREANOR, 2005, pp. 455-562) no sentido de sustentar a existência de um significativo judicial review em período anterior ao caso Marbury vs $M a-$ dison. É que, com efeito, poucos pesquisadores ousam a negar a sua existência pretérita, mas são enfáticos em afirmar que seriam casos remotos e isolados. Treanor, por sua vez, afirma que a prática do judicial review é quase imediata ao surgimento da Constituição norte-americana e derivaria, notadamente, pelo fato de a teoria constitucional anteceder toda doutrina do judicial review.

Há quem afirme, por sua vez, que a origem do judicial review é, essencialmente, corporativa/comercial (BILDER, 2006, pp. 502-566) e, por isso, pretérita. Diferentemente da versão "tradicional", que se apoia na premissa das teorias do direito ou na estrutura governamental, a autora sustenta que o judicial review nada mais seria do que a continuação da antiga prática inglesa da "doutrina da repugnância”. Por ela, já se entendia que a normas ordinárias do direito comercial não poderiam se opor às leis em geral. Essa prática da "repugnância" passou a ser aplicada no período colonial norte-americano.

Afirma-se, portanto, que a prerrogativa do magistrado em "repugnar" a norma ofensiva à Constituiçáo apenas fortaleceu a tese passado da prática colonial. Não haveria, portanto, uma criação originária de uma nova estrutura escalonada de normas

O Brasil recebeu bem essa ideia. Bem, em 1824, o país ganhava sua primeira Constituição. Nela não havia lugar para o controle de constitucionalidade das leis, já que a presença do Poder Moderador impedia que ao Poder Judiciário pudesse ser delegada a função de guardiāo da Constituição.

Com a proclamação da República, o cenário político modificou-se. A Constituição de 1891 extinguiu o Poder Moderador. Abriu-se campo para a introdução do controle de constitucionalidade. Ao Legislativo foi atribuída a guarda da Constituição, mas não privativamente. Além disso, previa caber recurso das sentenças das justiças dos Estados ao Supremo Tribunal Federal, quando houvesse contestação da validade de leis ou atos dos governos dos Estados em face da Constituição. 
Mas foi com a Constituição de 1934 que se introduziu o controle de constitucionalidade difuso no direito pátrio. $\mathrm{O}$ artigo 179 dispunha sobre a necessidade de maioria absoluta dos votos para que os tribunais declarassem a inconstitucionalidade de lei ou de ato de poder público. Trouxe, ainda, a possibilidade de suspensão, pelo Senado Federal, das leis declaradas inconstitucionais pelo Poder Judiciário (art. 91, IV).

O Estado ditatorial de Vargas refletiu no controle de constitucionalidade. A Constituição de 1937 manteve, em seu artigo 96, o que dispunha a Carta anterior. Acrescentouse, porém, um parágrafo único que possibilitava ao Presidente da República uma nova apresentação de lei considerada inconstitucional ao Parlamento, quando considerasse tal lei necessária. Caso o Parlamento confirmasse com dois terços de votos em cada Câmara, tornava-se sem efeito a decisão do Tribunal.

A Constituição de 1946 reverteu o quadro retirando o parágrafo único. Seu artigo 200 retomou o controle difuso, nos moldes da Carta de 1934.

A despeito do regime militar a que estava submetido o Brasil, as Constituiçóes de 1967 e 1969 (ou emenda, para os que assim entendem) mantiveram a possibilidade de controle difuso pelo Poder Judiciário (artigos 111 e 116, respectivamente).

A Constituição vigente manteve a tradição. É a inteligência de seu artigo 97.

\section{Uma Abordagem Crítica sobre os Efeitos no Tempo e no Espaço do Con- trole Incidental Concreto sob a Ótica do STF}

Em algumas decisóes, o STF passou a admitir o emprego no controle difuso da modulação de efeitos prevista no art. 27 da Lei 9868/99 para o modelo concentrado e também uma eficácia transcendente (ao interesse das partes do litígio concreto e à própria decisão), soluçóes que excepcionam a regra geral da eficácia limitada às partes e que merecem exame dos fundamentos respectivos.

O primeiro desses casos paradigmáticos foi o do RE n. 197.917-8, cujo julgamento teve início em 31.08.1999 e fim em 24.03.2004, com publicação do Acórdão em 07.05.2004.

O objeto sob controle era o art. 6_ da Lei Orgânica do Município paulista de Mira Estrela, acusado de malferir o parâmetro do art. 29, IV, da CF, no qual se exige uma relação de proporcionalidade entre o número de vereadores e o número de habitantes por município.

O Município em questão possuía 2.651 (dois mil, seiscentos e cinquenta e um) habitantes para 11 (onze) vereadores, quando em uma proporcionalidade aritmética devia ter apenas 9 (nove) vereadores. Por isso, entendeu o Ministro Relator, Maurício Corrêa, que o objeto sob controle era inconstitucional, ponderando contudo que, 
(...) a despeito de a legislatura a que se refere a decisáo de primeiro grau - quadriênio 1993/97 - já ter se exaurido, o presente recurso náo se acha prejudicado. Com efeito, a ação promovida pelo Parquet questionou a composiçáo da Câmara Legislativa do Município por entendê-la contrária à Carta da República, em face do excesso de representantes. Tal situaçáo persiste, porquanto os eleitores de Mira Estrela elegeram para o quadriênio 2001/2004 o mesmo quantitativo de 11 (onze) Vereadores. Remanesce, portanto, o interesse em reduzir esse número e a consequente declaração incidental de inconstitucionalidade da norma municipal.

Por isso, além da declaração de inconstitucionalidade, na conclusão do voto foi determinado à Câmara Legislativa que, após o trânsito em julgado, adote as medidas cabíveis para adequar sua composição aos parâmetros ora fixados.

A tese da inconstitucionalidade foi vencedora, pelo voto da maioria dos Ministros, mas os argumentos do Ministro Gilmar Mendes sobre a eficácia do julgamento são os que mais interessam à matéria em exame.

Em seu voto, referido Ministro assim se manifestou acerca da eficácia do julgado: 1) em caso de alegada inconstitucionalidade de lei eleitoral, aconselha-se que o Tribunal não proclame tal status quando o reconhecimento da nulidade não for capaz de resolver o problema e em lugar da pronúncia seja capaz de encontrar uma norma apta a preencher eventual lacuna no ordenamento; 2) em outras palavras, exige-se a necessidade de um outro princípio que justifique a não aplicação do princípio da nulidade, axioma que tem aplicação indistinta tanto ao controle concentrado quanto ao controle difuso, como mostra a experiência americana, na qual o controle é exclusivamente incidental e concreto, mas admite a restrição dos efeitos retroativos da pronúncia de inconstitucionalidade desde o caso Linkletter v. Walter $(1965)^{2}$, com base em critérios de política legislativa ${ }^{3}$; 3$)$ já no modelo alemão, no qual o controle é concentrado, a restrição dos efeitos retroativos da pronúncia de inconstitucionalidade é admitida desde o caso do regime de execução

2 Nesse caso foi negado ao impetrante de habeas corpus a mesma interpretaçáo antes reconhecida no caso Mapp v. Ohio (1961), no sentido da inadmissão de provas obtidas por meio ilícito, porque, embora tivesse ocorrido o mesmo em seu caso concreto, a condenação ocorrera perante uma corte estadual e o trânsito em julgado antes da decisão da Suprema Corte.

3 Em específico, a justificativa foi o problema que tal extensão generalizada traria para a administração da justiça. O argumento usado para tanto foi retórico: _ Constituiçáo nem proíbe nem exige efeito retroativo. Existe porém outra hipótese em que a restrição de efeitos é recomendada: quando há mudança de jurisprudência, ocasião em que a nova decisão passa a valer pro futuro (prospective overruling). Em alguns casos, a nova regra afirmada para decisão aplica-se aos processos pendentes (limited prospectivity); em outros, a eficácia ex tunc exclui-se de forma absoluta (pure prospectivity). Embora tenham surgido no contexto das alterações jurisprudenciais de precedentes, as prospectivity têm integral aplicação às hipóteses de mudança de orientação que leve à declaração de inconstitucionalidade de uma lei antes considerada constitucional. 
penal (Strafgefangene), de $1972^{4}$, com base em critério estritamente constitucional; 4) no direito pátrio prevalece ainda o princípio da nulidade da lei ou ato normativo inconstitucional, mas ele deve ser excepcionado nos casos em que se revelar absolutamente inidôneo para a finalidade perseguida (casos de omissão; exclusão de benefício incompatível com o princípio da igualdade), bem como nas hipóteses em que a sua aplicação pudesse trazer danos para o próprio sistema jurídico constitucional (grave ameaça à segurança jurídica); 5) assim, configurado eventual conflito entre o princípio da nulidade e o princípio da segurança jurídica, que, entre nós, tem status constitucional, a solução da questão há de ser, igualmente, levada a efeito em um processo de complexa ponderação; 6) no Brasil se deve supor que a pronúncia de inconstitucionalidade não afeta todos os atos singulares praticados com base na lei assim proclamada, precisamente em nome do princípio da segurança jurídica, cabendo aqui a distinção entre o efeito da decisão no plano normativo (Normebene) e no plano do ato singular (Einzelaktebene); 7) a regra do art. 27 da Lei 9868/99, que confere ao STF discricionariedade na fixação dos limites temporais da pronúncia de inconstitucionalidade no controle concentrado e abstrato, permite que se pondere, com vista em razóes de segurança jurídica, se a supressão da norma poderá ser mais danosa para o sistema do que a sua preservação, de modo semelhante à decisão de apelo ao legislador do direito alemáo ${ }^{5}$, devendo ser aplicada também ao controle difuso e concreto, com base no mesmo juízo de ponderação; 8) os modelos mais próximos do direito nacional são o português e o alemão, porque também aqui a não-aplicação do princípio da nulidade não se há de basear em consideração de política judiciária, mas em fundamento constitucional próprio; 9) no caso em comento, eventual decisão retroativa atingiria atos da Câmara Municipal praticados tanto antes (fixação do número de vereadores, fixação do número de candidatos e definição do quociente eleitoral) quanto depois do pleito (validade das deliberaçóes da edilidade nos projetos e lei aprovados), de modo que um juízo rigoroso de proporcionalidade recomenda a preservação do modelo legal existente na atual legislatura, cabendo ao legislativo municipal estabelecer nova disciplina sobre a matéria, em tempo hábil para que se regule o próximo pleito eleitoral (declaração de inconstitucionalidade pro futuro).

No final dos debates, o Ministro Nelson Jobim advertiu que o entendimento vencedor devia ser submetido ao Tribunal Superior Eleitoral, comprometendo-se então o

4 Nesse caso, algumas restriçóes gerais relativas à execução da pena, antes consideradas constitucionais porque implícitas à condição dos condenados (como a intercepçáo de correspondência), foram reconhecidas como inconstitucionais, admitindo-se todavia a sua manutenção até que o legislador alterasse a lei. No entendimento da Corte Constitucional, a Lei Fundamental, enquanto ordenação objetiva de valores com ampla proteçáo dos direitos fundamentais, náo pode admitir uma restrição ipso jure da proteção dos direitos fundamentais para determinados grupos de pessoas.

5 Em outras palavras, o princípio da nulidade somente há de ser afastado se se puder demonstrar, com base numa ponderação concreta, que a declaração de inconstitucionalidade ortodoxa envolveria o sacrifício da segurança jurídica ou de outro valor constitucional materializável sob a forma de interesse social. 
Ministro Sepúlveda Pertence a fazê-lo, com o objetivo de dar uma orientação uniforme a esse respeito para todo o País, naquilo que o Ministro Gilmar Mendes chamou de efeito transcendente.

Como se observa, o STF não conferiu uma eficácia erga omnes autônoma à decisão no controle difuso, recomendando porém (i) a modulação de efeitos pro futuro, mediante ponderação entre a preservação da segurança jurídica dos atos praticados com base no dispositivo questionado em sua constitucionalidade e a sua retirada do ordenamento com base no princípio da_nulidade, e (ii) a possível extensão do resultado a terceiros, com base em competência normativa alheia (no caso, o TSE).

E assim ocorreu: o Ministério Público Eleitoral apresentou Representação junto ao TSE, para que desse uniformidade à decisão acima relatada, e aquele Tribunal editou a Res. n. 21.702/2004, que foi objeto por sua vez das ADI's ns. 3345 e 3365 (esta última teve os autos apensados à primeira), julgadas improcedentes no pressuposto da constitucionalidade náo apenas do poder normativo primário do TSE, como também pelo fato de apenas haver replicado a interpretação do STF, na qualidade de intérprete máximo da $\mathrm{CF}$, dando concreçáo ao princípio da força normativa da constituição.

O Ministro Relator daquelas ADI's, Celso de Mello, chamou o efeito transcendente de efeito irradiante e atribuiu seu tratamento anterior ao julgamento da Reclamação n. $1987^{6}$, que tinha por objeto alegado descumprimento pelo TRT-10 do julgamento contido na ADI n. 1662, em cuja razão de decidir consta que o sequestro previsto no art. 100 da CF somente é admitido em caso de violação da ordem de pagamento (seja de créditos alimentares ou comuns), e não quando há falta de inclusão do débito no orçamento ou pagamento inidôneo (a menor ou fora do prazo). O ato normativo objeto daquela ADI era a IN n. 11/97 do TST, que após o deferimento de medida liminar foi substituída pelo Provimento n. 03/98, adequado aos termos daquela decisão interlocutória.

Sobreveio entáo a EMC n. 30, alterando o regime dos precatórios, e quando do julgamento definitivo da ADI o STF entendeu que as mudanças contidas naquela Emenda não alteravam a ratio decidendi contida na medida liminar. A polêmica, então, passou a ser o cabimento da Reclamação quando o seu objeto devia ser supostamente outro (um ato normativo do TST, e não uma decisão do TRT-10), razão pela qual o tema da eficácia transcendente foi suscitado. $\mathrm{O}$ efeito transcendente teria então conotação não apenas

6 No mesmo voto o Ministro Relator cita a medida liminar deferida pelo Ministro Relator Gilmar Ferreira Mendes nos autos da Reclamação n. 2126, datada de 19.08.2002, na qual consta que a eficácia da decisão do Tribunal transcende o caso singular, de modo que os princípios dimanados da parte dispositiva e dos fundamentos determinantes sobre a interpretação da Constituição devem ser observados por todos os Tribunais e autoridades nos casos futuros. Contudo, em 01.02.2008 o Reclamante pediu desistência e referido incidente não chegou a ser julgado no mérito, de modo que não pode servir de parâmetro para a uniformização da matéria junto ao STF, coisa que somente se alcançou na Reclamação n. 1987. 
objetiva, focada na interpretação do dispositivo controlado, como também subjetiva, já que a decisão poderia alcançar entes diversos daquele que editou o ato sob controle, como bem lembrou o Ministro Sepúlveda Pertence ao criticar o exame dessa matéria em sede de Reclamação: "então, quando julgarmos da constitucionalidade ou não de uma lei estadual, os outros Estados que tenham leis similares virão aqui, não com uma ação direta, mas com uma reclamação".

De fora parte a polêmica sobre o cabimento da Reclamação naquela hipótese, o tema da eficácia transcendente somente foi tratado em pormenor no voto do Ministro Gilmar Ferreira Mendes, assim resumido: 1) o efeito vinculante das açóes de controle concentrado alcança não apenas a parte dispositiva do Acórdão, como também suas razóes ou seus fundamentos determinantes, porque a sua concepção na PEC que resultou na EMC n. 3/93 está desde sempre vinculada ao modelo previsto no $\$ 3^{\circ}$ da Lei Orgânica da Corte Constitucional alemá; 2) no modelo alemão, oscilou-se entre o extremo que abrange inclusive os obter dicta e aquele que nega tal extensão para além da coisa julgada tradicional para por fim se aceitar orientaçóes mediadoras, como a proposta por Klaus Vogel, para quem a coisa julgada alcança também a norma decisória concreta, correspondente à ideia jurídica subjacente à formulação contida na parte dispositiva, que, concebida de forma geral, permite não só a decisão do caso concreto, mas também a decisão de casos semelhantes; 3) o próprio STF já estaria a aplicar tal eficácia no controle difuso de leis municipais, ao estender a um RE as razóes de decidir tomadas anteriormente em outro RE a propósito de outras leis municipais de conteúdo semelhante (RE's ns. 228.844, 221.795, $364.160,423.252$, 345.048 e 384.521); 4) _tal procedimento evidencia, ainda que de forma tímida, o efeito vinculante dos fundamentos determinantes da decisão exarada pela Corte Constitucional.

A Ementa do Acórdão de referida Reclamação incluiu a solução apresentada pelo Ministro Gilmar Mendes, mas algumas observaçóes devem ser feitas a seu respeito: 1) entre os extremos teóricos acima citados, o conceito de norma decisória concreta parece parar nos limites da ratio decidendi, portanto sem incluir os obter dicta; 2) há um sério problema conceitual envolvido nas expressóes efeito vinculante e efeito transcendente, porque elas não expressam a mesma coisa: efeito vinculante significa a vedação de decisóes em sentido contrário, enquanto que efeito transcendente significa o transporte ${ }^{7}$ das razóes de decidir de uma decisão para outra ação, outro recurso ou outro ato normativo (como ocorreu com a Res. TSE n. 21.702/2004); 3) logo, quando se trata de sujeitar outros sujeitos passivos diversos daqueles que editaram o ato sob controle a uma determinada

7 Expressão tomada de empréstimo do transporte da coisa julgada coletiva in utilibus (e secundum eventum litis) prevista no $\$ 3$ _ do art. 103 do CDC, para os casos de condenação coletiva com posterior liquidação individual. No caso em exame, porém, o transporte não se faz do campo coletivo para o campo individual, mas de uma decisão para outra. 
decisão, está-se falando em eficácia vinculante, e quando se trata de estender uma decisão a outro processo com pano de fundo semelhante, está-se falando em eficácia transcendente; 4) com isso, os exemplos do controle difuso de leis municipais se enquadra no segundo conceito, enquanto que a extensão subjetiva da $\mathrm{ADI}$ n. 1662 se insere no primeiro; 5) portanto, não é propriamente a natureza do controle que é determinante da distinção entre tais conceitos, e sim a sua ontologia.

O parêntese da Reclamação n. 1987-0 esclarece melhor agora o voto do Ministro Gilmar Ferreira Mendes nos autos das ADI's ns. 3345 e 3365.

Depois de voltar aos exemplos de eficácia transcendente (que também chamou de vinculante) em sede de controle difuso de leis municipais, inclusive para dispensar a intervenção do Senado, pela via do art. 52, $\mathrm{X}$, da $\mathrm{CF}^{8}$, referido Ministro citou ainda os seguintes fundamentos para seu entendimento: 1) tal eficácia teria como fundamento também o caput do art. 557 do CPC, já que as Turmas têm considerado dispensável, no caso de modelos legais idênticos, a submissão da questão ao Plenário; 2) no controle por via de açôes coletivas (ação civil pública e mandado de segurança coletivo) a eficácia erga omnes da decisão que se acha nelas possibilitada também dispensa a intervenção do Senado e inclusive pode prejudicar ADI posterior (ADI n. 1919) $\left.{ }^{9} ; 3\right)$ a parte final do parágrafo único do art. 481 do CPC dispensa os tribunais inferiores de submeter a questão constitucional ao pleno ou ao órgão especial (art. $97 \mathrm{da} \mathrm{CF}$ ) quando a matéria já houver sido examinada pelo STF em sede de controle difuso; 4) os modelos de controle têm a mesma natureza, o que explica os efeitos gerais ou transcendentes também no controle difuso; 5) a modulação de efeitos do art. 27 da Lei n. 9868/99 é uma técnica de harmonização do modelo misto brasileiro, especialmente nos casos de mudança de jurisprudência.

Também aqui são necessárias algumas observaçôes, a saber: 1) as hipóteses do parágrafo único do art. 481 e do caput do art. 557 do CPC são mesmo de eficácia transcendente, porque decisóes anteriores do STF em sede de controle difuso podem ser transportadas para decisôes de órgãos fracionários dos tribunais inferiores e para as turmas do próprio STF, respectivamente, sem a necessidade de decisão do órgão especial ou do pleno que as confirme, mas essa eficácia não é propriamente vinculante, já que a rigor o órgáo especial ou o pleno pode examinar a matéria, seja para confirmar a decisão anterior, seja para excepcioná-la em caso de distinguish; 2) no caso das açôes coletivas em que há controle de constitucionalidade incidental existem duas facetas: a) a dispensa de intervenção posterior do Senado (especificamente nas ações civis públicas contra leis e atos

8 Providência que havia sido considerada desnecessária nos debates finais do julgamento do RE n. 197.9178 por motivos óbvios, já que a suspensão de lei municipal já teria sido superada pela invalidade declarada na própria decisão do STF.

9 A ADI em questão foi considerada prejudicada porque seu objeto (Res. n. 556/97, do Conselho Superior da Magistratura Paulista) já havia sido fulminado em sede de mandado de segurança coletiva pelo STJ. 
normativos municipais) não implica em transporte das razóes de decidir, precisamente porque a intervenção é considerada redundante, não havendo assim qualquer decisão posterior para a qual o resultado seja conduzido; b) a prejudicialidade potencial de futura ADI depende náo apenas do status do órgáo julgador na estrutura judiciária, como também do resultado da demanda, mas de alguma forma há também o transporte das razôes de decidir sobre a decisão extintiva da $\mathrm{ADI}$, já que se pode antever o seu resultado coincidente (no caso da ADI n. 1919 a extinção acabou por referendar a decisão do STJ) ou prejudicial (como ocorreu com a ADI n. 4071-5, adiante analisada); 3) novamente, a identidade ontológica entre os modelos de controle difuso e concentrado explica não apenas a distinção entre efeitos transcendentes e efeitos vinculantes, como também justifica a modulação de efeitos.

Na ordem cronológica (invertida acima com o exame das ADI's ns. 3345 e 3365 e da Reclamação n. 1987-0, em sequência do RE n. 197.917-8), o segundo paradigma foi o julgamento do HC n. 82.959-7 (publicado em 01.09.2006), que depois serviu de leading case para a Súmula Vinculante n. 26 (JEVEAUX, 2012), que tem a seguinte redação:

Para efeito de progressáo de regime no cumprimento de pena por crime hediondo, ou equiparado, o juízo da execuçáo observará a inconstitucionalidade do art. 2_ da Lei n. 8072, de 25 de julho de 1990, sem prejuízo de avaliar se o condenado preenche, ou náo, os requisitos objetivos e subjetivos do benefício, podendo determinar, para tal fim, de modo fundamentado, a realizaçáo de exame criminológico.

O texto supra resume o resultado do julgamento, no qual a tese da inconstitucionalidade foi vencedora por maioria, tendo o Ministro Gilmar Mendes repetido a parte do voto do paradigma anterior acerca da modulação de efeitos no controle difuso e concluído que se devia conferir eficácia ex nunc à pronúncia de inconstitucionalidade do $\$ 1^{\circ}$ do art. $2^{\circ}$ da Lei 8072/90, entendendo-se como aplicável às condenaçóes que envolvam situaçóes ainda suscetíveis de serem submetidas ao regime de progressão.

No voto seguinte, da Ministra Ellen Gracie, seguiu-se uma crítica à modulação de efeitos, em especial acerca do caráter pro futuro (pure prospectivity), porque nessa hipótese a solução sequer seria aplicável ao paciente do habeas corpus em julgamento, além de ter utilidade apenas para o caso concreto. Tampouco seria hipótese de efeitos limitados ao paciente (limited prospectivity), por conta de um obstáculo lógico: se as sentenças já publicadas ficam resguardadas da nova interpretação, pelo bom motivo de que os juízes que as proferiram não poderiam prever que a jurisprudência assente da Casa - e tantos anos após a promulgação da nova Constituição - se fosse reverter dessa sorte, como excetuar dessa salvaguarda a sentença condenatória no caso presente? $\mathrm{O}$ juiz que prolatou, tanto quanto o TJSP, encontrava-se na mesma situação fática de insciência ou imprevisibilidade de todos os seus demais colegas. 
Em resumo, a Corte estaria se avocando um arbítrio excessivo ao 'selecionar' quais réus serão beneficiados retroativamente por seu novo entendimento.

Essa última parte do voto provocou um interessante debate no qual o Ministro Gilmar Mendes revelou a preocupação que o levou a propor a eficácia retroativa para o caso concreto em julgamento e a eficácia prospectiva para os demais casos semelhantes. Em suas palavras, ao se reconhecer a inconstitucionalidade de uma lei que era antes declarada constitucional, vamos ter de fazer uma série de perguntas, inclusive, em matéria penal, como por exemplo, a responsabilidade civil do Estado e tudo mais.

Trocando em miúdos, também no modelo brasileiro essa modulação de efeitos no controle difuso, em específico quanto à matéria penal, leva em conta razóes de ordem política, e não estritamente de ordem constitucional. Afinal, como bem apontou o Ministro Sepúlveda Pertence, essa declaração, na verdade, equivale à introdução de uma lei penal mais benéfica e, esta, até por imperativo constitucional, teria de aplicar-se. A essa observação o Ministro Gilmar Mendes opôs o seguinte: "não posso supor que o Estado vá agora responder pela prisão, se se considera que era constitucional à época”, no que foi jocosamente retrucado pelo Ministro Sepúlveda pertence: "haveria, primeiro, ação regressiva contra o Brossard e o Rezek".

Apesar desse elegante sarcasmo ${ }^{10}$, o que mais preocupa, em termos argumentativos, não é a justificativa da modulação de efeitos no controle concreto, que em tese é mesmo possível, na linha de exposição do Ministro Gilmar Mendes, mas sim a opção por um modelo supostamente imunizado de razóes políticas de decidir, quando as razóes estritamente constitucionais de decidir não são assim tão imunes a questôes de política judiciária ou econômica.

O tema foi novamente tratado no voto do Ministro Nelson Jobim (Presidente), que assim se manifestou:

(...) é certo que, historicamente, o Supremo Tribunal Federal já, diversas vezes, modulou, no controle difuso, à vista da circunstância ou do caso concreto ou da equaçáo jurídica do caso concreto, os seus efeitos. Lembro a mais recente e expressiva delas: a do cancelamento da Súmula 394, quando se estabeleceu, por decisáo unânime do

10 Falando sério mais adiante, e ainda a propósito do mesmo assunto, registrou o Ministro Sepúlveda Pertence a seguinte advertência acerca da modulação proposta pelo Ministro Gilmar Mendes para o caso em julgamento e especialmente para os demais semelhantes: _náo se está impondo ao juízo das execuçóes que abra as portas indistintamente: há de examinar caso a caso a ocorrência dos pressupostos da progressão, abstraída apenas a vedação legal que se declara inconstitucional. Depois, em seu voto, renovou a advertência: isso não impedirá que o condenado, que esteja, ainda, a cumprir a sua pena, postule a progressão de regime. Vale lembrar que no debate acima relatado a eficácia prospectiva para os demais casos semelhantes se aplicaria pelo restante da pena a cumprir. De acordo com o Ministro Gilmar Mendes, _se houver ainda um dia de pena, teremos a progressão. 
Plenário, que a nova orientaçáo seria inaplicável aos processos findos. E, também, o caso dos vereadores no qual, em nome da segurança das regras do jogo eleitoral, náo se quis cortar, além da metade, o mandato que fora disputado para número de vagas que o Tribunal depois entendeu exagerado.

No fim do julgamento a matéria voltou à tona, com o Ministro Gilmar Mendes renovando sua preocupação com a real causa da modulação dos efeitos, ou seja, a potencial responsabilidade civil do Estado por erro judicial ou prisão excessiva, fazendo então o Ministro Sepúlveda Pertence duas propostas: 1) deixar claro que a decisão não se aplica a eventuais consequências jurídicas às penas extintas; 2) que a decisão fosse comunicada ao Senado, decerto para os fins do art. 52, X, da CF. Essa última proposta daria à decisão um caráter erga omnes e pro futuro, mas essa já era a proposta do Ministro Gilmar Mendes, e que acabou depois generalizada no julgamento da Reclamaçáo n. 4335-5, na qual o STF passou a atribuir ao Senado uma função meramente formal de publicaçáo da decisão do tribunal acerca da inconstitucionalidade, reservando à própria decisão o efeito erga omnes.

Em resumo, no voto do Ministro Gilmar Mendes a decisão em si mesma teria eficácia erga omnes para as condenaçóes que envolvam situaçóes ainda suscetíveis de serem submetidas ao regime de progressão, mas para o Ministro Sepúlveda Pertence tal generalização dependia da suspensão do dispositivo inconstitucional pelo Senado. Seja como for, a edição de Súmula Vinculante acabou por dar eficácia erga omnes e vinculante à matéria, já que nenhum juízo criminal pode decidir em sentido contrário após a sua publicação. Na realidade, para Pertence, a adoção da Súmula Vinculante seria a melhor forma de apaziguar o rigor do entendimento do ministro Gilmar Mendes, para quem o art. 52, X já não teria lugar na atual Constituição. É que, segundo Pertence,

(...) A Emenda Constitucional 45 dotou o Supremo Tribunal de um poder que, praticamente, sem reduzir o Senado a um órgáo de mera publicidade de nossas decisóes, dispensa essa intervençáo. Refirome, é claro, ao instituto da súmula vinculante, que a Emenda Constitucional 45, de 2005, veio a adotar depois de mais de uma década de tormentosa discussáo. De tal modo que reproduzirei no meu voto, para efeitos didáticos, o dispositivo do vigente art. $102, \$ 3^{\circ}$ que vincula, ele sim, a súmula vinculante, editada na conformidade da Lei de 2006, que a disciplinou. Vincula, nos termos da Constituiçáo, sim, náo apenas os tribunais, no que o eminente Ministro Gilmar Mendes, cada vez mais religioso, chama de efeitos transcendentes, mas este restrito aos tribunais que tenham de enfrentar a mesma questáo de inconstitucionalidade. $\mathrm{E}$ tenho dúvidas se até ai seria vinculante, porque a dispensa da remessa ao Plenário da argüiçáo de inconstitucionalidade náo impede o tribunal inferior de alterá 
-la enquanto náo dotada a jurisprudência do Supremo Tribunal do efeito vinculante, que, ou decorre, no nosso sistema, de decisóes nos processos objetivos de controle direto, ou decorrerá da adoçáo solene, pelo Tribunal, da súmula vinculante. Esta, sim, vinculante de todos os demais órgáos do Poder Judiciário, salvo o próprio Supremo Tribunal, e dos órgáos da Administraçáo Pública Federal, Estadual e Municipal.

Como se percebe, no primeiro (RE n. 197.917-8) e no segundo (HC n. 82.9597) paradigmas as decisóes reclamaram um complemento decisório para se generalizar, o que permite concluir que a eficácia transcendente acabou se reduzindo à eficácia erga omnes, ou ainda, que a primeira náo possui autonomia para produzir simultaneamente a segunda.

O último paradigma é o julgamento do Agravo Regimental de decisão terminativa do Ministro Relator Menezes Direito tomada na ADI n. 4071-5, na qual o processo foi extinto sumariamente sem a resolução do mérito, com base no art. 4_ da Lei n. 9868/99, no pressuposto de que o objeto impugnado (art. 56 da Lei n. 9430/96) já havia sido proclamado constitucional em sede de dois recursos extraordinários (RE's 377.457 e 381.964) e de que não se apresentavam novos argumentos relevantes ou mudança de ordem jurídica, social ou econômica suficientes para justificar a mudança de entendimento anterior, antevendo-se com isso a manifesta improcedência do pedido.

Com efeito, dispóe o art. $4^{\circ}$ da Lei n. 9868/99 que a petiçáo inicial de ADI pode ser indeferida quando manifestamente improcedente, de modo que a questão que devia ter sido resolvida era a da possibilidade de dois julgamentos anteriores tomados em sede de controle difuso, em sentido contrário à tese contida na $\mathrm{ADI}$, serem capazes de indicar a sua manifesta improcedência. Contudo, o STF não se ocupou dessa matéria e gastou todo o julgamento decidindo em questáo de ordem sobre o limite temporal de ingresso de amicus curiae em sede de ADI, fixando finalmente o entendimento de que ele coincide com a data imediatamente anterior à da liberação do processo para a pauta pelo Relator. Com isso, somente se pode deduzir que a maioria seguiu a mesma interpretação do Relator, ao indeferir a petição inicial da $\mathrm{ADI}$, inclusive quanto a sua ressalva.

Para o que interessa ao tema em estudo, o caso foi de atribuição de eficácia também transcendente aos julgados dos RE's, não porém sobre relaçóes jurídicas materiais idênticas àquelas da ratio decidendi, mas sobre $\mathrm{ADI}^{\prime}$ s e $\mathrm{ADC}^{\prime}$ s futuras, numa espécie de simbiose entre os modelos difuso e concentrado.

\section{Conclusões}

De tudo isso é possível concluir que: 
1) a eficácia vinculante significa a proibição de decisóes em sentido contrário àquele da ratio decidendi estabelecida em sede de controle concentrado, fenômeno que não se verifica em nenhuma decisão tomada em sede de controle difuso;

2) tanto assim que nos dois primeiros paradigmas acerca da matéria examinada houve a necessidade de um ou mais complementos decisórios capazes de gerar efeitos vinculantes, a saber: a) no RE 197.917-8, o julgamento das ADI's ns. 3345 e 3365 no sentido da constitucionalidade da Res. TSE n. 21.702/2004, que produziu o resultado de uma ADC procedente (efeito dúplice), proibitivo de decisôes em sentido contrário; b) no HC n. 82.959-7, a Súmula Vinculante n. 26;

3) a eficácia transcendente ou irradiante expressa o transporte das razóes de decidir de uma decisão para outra ação, outro recurso ou outro ato normativo (como ocorreu com a Res. TSE n. 21.702/2004), ou seja, trata-se de estender uma decisão a outro processo com pano de fundo semelhante, e não de sujeitar outros sujeitos passivos diversos daqueles que editaram o ato sob controle a uma determinada decisão (eficácia vinculante);

4) com isso, a eficácia transcendente se reduz à eficácia erga omnes, ou ainda, a primeira não possui autonomia para produzir simultaneamente a segunda;

5) são exemplos então de eficácia transcendente: a) as decisóes tomadas pelo STF em sede de controle difuso de leis municipais, ao estender a um RE as razóes de decidir tomadas anteriormente em outro RE a propósito de outras leis municipais de conteúdo semelhante (RE's ns. 228.844, 221.795, 364.160, 423.252, 345.048 e 384.521); b) as hipóteses do parágrafo único do art. 481 e do caput do art. 557 do CPC, porque decisóes anteriores do STF em sede de controle difuso podem ser transportadas para decisóes de órgãos fracionários dos tribunais inferiores e para as turmas do próprio STF, respectivamente, sem a necessidade de decisão do órgão especial ou do pleno que as confirme; c) as decisóes em sede de controle difuso capazes de prejudicar o julgamento de ADI's por se antever o resultado coincidente (no caso da ADI n. 1919 a extinção acabou por referendar a decisão do STJ) ou prejudicial (como ocorreu com a ADI n. 4071-5, ao se referendar decisóes anteriores em dois RE's);

6) não ocorre porém eficácia transcendente nas açóes civis públicas contra leis e atos normativos municipais, porque a dispensa de intervenção posterior do Senado não implica em transporte das razóes de decidir, precisamente porque a intervenção é considerada redundante, não havendo assim qualquer decisão posterior para a qual o resultado seja conduzido; 
7) já a modulação de efeitos prevista no art. 27 da Lei n. 9868/99 para o controle concentrado tem perfeito cabimento no controle difuso, tanto pela identidade ontológica entre tais modelos, como também porque em vários casos concretos se exige um cálculo de proporcionalidade entre a preservação da segurança jurídica dos atos praticados com base no dispositivo questionado em sua constitucionalidade e a sua retirada do ordenamento com base no princípio da nulidade.

\section{Referências}

ATAÍDE JÚNIOR, Jaldemiro Rodrigues de. Precedentes Vinculantes e Irretroatividade do Direito no Sistema Processual Brasileiro: os precedentes dos tribunais superiores e sua eficácia temporal. Curitiba: Juruá, 2012.

BILDER, Mary Sarah. The Corporate Origins of Judicial Review. The Yale Law Journal, Vol. 116, No. 3 (Dec., 2006), pp. 502-566.

FERNANDES, Antonio Scarance. Incidente processual: Questáo incidental: Procedimento incidental. São Paulo, Revista dos Tribunais, 1991.

JEVEAUX, Geovany Cardoso. Teorias do Estado e da Constituiçáo. Rio de Janeiro: GZ, 2015.

MIRANDA, Pontes de. Comentários a constituição de 1946. Rio de Janeiro: H. Cahen, 1947.

MONNERAT, Fábio Victor da Fonte Monnerat. Efeitos Objetivos do Julgamento do Recurso Extraordinário. Revista da Faculdade de Direito da Universidade São Judas Tadeu. n. 1, primeiro semestre de 2014.

PRAKASH, Saikrishna B.; Yoo; John C. The origins of judicial review. The University of Chicago Law Review, Vol. 70, No. 3 (Summer, 2003), pp. 887-982.

PEGORARO, Lucio. A Circulação, a Recepção e a Hibridação dos Modelos de Justiça Constitucional. Revista Latino-Americana de Estudos Constitucionais. Belo Horizonte: Del Rey, n. 6, jul/dez 2005, pp. 235-261.

SEGADO, Francisco Fernández. La Justicia Constitucional Ante el Siglo XXI: La Progresiva Convergencia de los Sistemas Americano y Europeo-kelseniano. Cidad de México: Universidad Nacional Autónoma de México, 2004.

SOUZA, Marcelo Alves Dias de. Do Precedente Judicial à Súmula Vinculante. Curitiba: Juruá, 2011.

TREANOR, William Michael. Judicial Review before "Marbury". Stanford Law Review, Vol. 58, No. 2 (Nov., 2005), pp. 455-562. 
TUCCI, José Rogério Cruz. Precedente Judicial Como Fonte do Direito. São Paulo: RT, 2004.

YAZBEK, Otávio. Consideraçóes Sobre a Circulaçáo e Transferência dos Modelos Jurídicos. In: GRAU, Eros Roberto e GUERRA FILHO, Willis Santiago (org.). Direito Constitucional. Estudos em Homenagem a Paulo Bonavides. São Paulo: Malheiros, 2001, pp. 540-557.

ZANETI JÚNIOR, Hermes. O Valor Vinculante dos Precedentes. Salvador: Jus Podivm, 2015.

ZAVASCKI, Teori Albino. Eficácia das Sentenças na Jurisdição Constitucional. São Paulo: RT, 2001. 